\title{
Prominent Doses of Nitrogen Enhance Mulberry and Silk Cocoon Productivity
}

\author{
Faruque Ahmed, Md. Shakhawat Hossain, Md. Aftab Uddin, and Oli Ahmed
}

\section{ABSTRACT}

Nitrogen (N) has potential to improve leaf yield and quality of mulberry plant. However, optimum doses of $\mathbf{N}$ for mulberry cultivation have not been updated for long times on the newly developed mulberry varieties in Bangladesh. A study was conducted at the research field and laboratories of Bangladesh Sericulture Research and Training Institute (BSRTI), Rajshahi to determine the nitrogen $(N)$ requirements and optimum age of mulberry plants to get higher leaf yield, better quality of leaves, successful silkworm rearing performance and suppresses of foliar diseases in mulberry plant. The six treatments executed for trials on $\mathbf{N}$ requirements of mulberry plants were: $\mathrm{N}: 0,80,160,240,320$ and $400 \mathrm{~kg} / \mathrm{ha} / \mathrm{yr}$. The blanket doses of $P \& \mathrm{~K}$ for $\mathrm{N}$ trial were fixed as per recommended doses of BSRTI. Research results indicated that the added nutrient elements $(N)$ favored in increasing growth, leaf yield, improving quality of mulberry leaves, suppresses foliar diseases as well as improved silk cocoon productivity. The leaf yield increased with increased rates of $N$ application. The highest leaf yield was $51.88 \mathrm{Mt} / \mathrm{ha} / \mathrm{yr}$ found in older plants of 6-10 years of age with the application of $N$ @ $400 \mathrm{~kg} / \mathrm{ha} / \mathrm{yr}$ which was $6.57 \%$ higher than the maximum average yield of less than 5 years ages of mulberry plant. All the growth and quality parameters of leaves viz: moisture, chlorophyll-a, chlorophyll-b, total sugar, soluble carbohydrate, reducing sugar and crude protein exhibited the best performance with the better silkworm rearing performances viz: wt. of 10 matured larval (g), effective rate of rearing by number, single cocoon wt. (g), single shell wt. (g), SR\%, highest filament length $(\mathrm{m})$, rendita and cocoon yield/100 dfls (kg) through the treatment of $N_{400} P_{150} K_{100} \mathrm{~kg} / \mathrm{ha} / \mathrm{yr}\left(T_{5}\right)$ with four split doses in 6-10 years ages of mulberry plant, where the cocoon productivity was $57.85 \%$ greater than the control treatment. Furthermore, the average incidence percentages of leaf spot, tukra and powdery mildew diseases were also reduced for the increasing doses of nitrogen. This study concluded that elevated $\mathrm{N}$ enhances mulberry leaf yield, quality, silk cocoon productivity as well as suppresses the foliar diseases incidence of mulberry plant.

Keywords: Chlorophyll, leaf quality, leaf spot, powdery mildew, silk cocoon, tukra.

\section{INTRODUCTION}

Mulberry (Morus spp) is an economically and traditionally very important deciduous plant for the development of sericulture industry. This plant is mainly cultivated to harvest leaves for the rearing of silkworms [1]. The quality mulberry leaf fed to silkworms is the most important factor that influences the successful cocoon production by mulberry silkworm [2]. Because the improvement of larvae and cocoon characters of the silkworms has been witnessed with the increase in the nutritional status of mulberry leaf [3]. Quality mulberry leaf is the basic requirements of sericulture that plays a key role for successful silkworm cocoon crop [4].

Quality leaf production in mulberry is highly dependent on the supply of various inputs especially nitrogen fertilizers [5].
Submitted : November 15, 2021

Published : January 10, 2022

ISSN: $2684-1827$

DOI: $10.24018 /$ ejfood.2022.4.1.415

\section{Faruque Ahmed *}

Senior Scientific Officer, Bangladesh Sericulture Research and Training Institute (BSRTI), Rajshahi, Master of Science in Agronomy, Department of Agronomy and Agricultural Extension, $\mathrm{PhD}$ Fellow, Rajshahi University, Bangladesh.

(e-mail: moistfaruk@gmail.com)

Md. Shakhawat Hossain

Senior Scientific Officer, Bangladesh Sericulture Research and Training Institute (BSRTI), Rajshahi, Master of Chemistry (Organic), Rajshahi University, PhD Fellow, Rajshahi University, Bangladesh. (e-mail: mithu400sh@ gmail.com)

Md. Aftab Uddin

Senior Scientific Officer, Bangladesh Sericulture Research and Training Institute (BSRTI), Rajshahi, Master of Zoology, Rajshahi University, Bangladesh

(e-mail: aftabbsrti@gmail.com)

Oli Ahmed

Personal Assistant to Director, Bangladesh Sericulture Research and Training Institute (BSRTI), Rajshahi, Master of Political Science, National University, Bangladesh and $\mathrm{PhD}$ Fellow, Jahangirnagar University, Bangladesh. (e-mail: olibsrti@gmail.com)

*Corresponding Author
Among the NPK nitrogen is the main plant nutrient that has a key role in the growth, metabolism, and development of plants [6]. Application of $\mathrm{N}$ significantly influenced the mulberry leaf yield, quality, and cocoon characters of silkworm race [7]. Mulberry responds to nitrogen since it is a constituent of plant proteins, nucleic acids, and vitamins [8]. The digested $\mathrm{N}$ used for moth and eggs was more effective at early spring silkworm rearing [9].

Mulberry plant is affected by a number of diseases caused by fungi, bacteria, viruses and nematodes [10], [11]. Among the major foliar diseases of mulberry plant powdery mildew, leaf spot, leaf rust and tukra are the economically important which reduce the leaf production as well as depletion of leaf quality feed to silkworm [12], [13]. Nitrogen fertilization has an additional potentiality to suppress of fungal pathogens 
[14]. But the nitrogen disease hypothesis states that plant growth at high nitrogen $(\mathrm{N})$ availability may result in increased plant susceptibility to pathogens as a result of increased foliar nitrogen concentrations [15]. So, it is essential to investigate the impact of elevated nitrogen on common diseases of mulberry plant.

However, such type of study is not available, to quantify elevated $\mathrm{N}$ effect on mulberry plant production, silkworm rearing performance and suppression of common diseases during mulberry growth period. Therefore, this study was carried out to quantify the optimum level of $\mathrm{N}$ need to be applied in soil along with BSRTI, recommended basal dose of $\mathrm{P}$ and $\mathrm{K}$ to get maximum mulberry leaf yield, quality, cocoon productivity and suppress of common foliar diseases of mulberry plant. It was hypothesized that the application of different levels of $\mathrm{N}$ with recommended basal doses of $\mathrm{P}$ and $\mathrm{K}$ will be increased the mulberry leaf yield, improved leaf quality, suppress the infestation rate of common diseases as well as ensured the successful silk cocoon production.

\section{MATERIALS AND METHODS}

\section{A. Experimental Site}

This experiment was conducted in the experimental field of the Bangladesh Sericulture Research and Training Institute (BSRTI), Rajshahi, Bangladesh which is located at the $24^{\circ} 22^{\prime} 29^{\prime \prime} \mathrm{N}$ and $88^{\circ} 37^{\prime} 84^{\prime \prime} \mathrm{E}$.

\section{B. Experimental Plant}

Mulberry (Morus spp) variety BM-11 (BM = Bangladesh Mulberry) and high-bush plantation system was used for this study. Mulberry plant (Morus spp) is small to medium sized shrubs or trees with a thick tan-gray ridged trunk which is perennial, deep rooted and hardy in nature. Due to its perennial, deep rooted and hardy habit, mulberry is grown in wide range of soil and agro-climatic conditions in Bangladesh.

\section{Experimental Condition}

In Bangladesh the silkworm is reared in four commercially rearing seasons for every year. Depending upon the silkworm rearing season for this experiment the mulberry garden was pruned four times in a year each after three months interval. Two types of mulberry plant viz: (0-5) and (6-10) year's mulberry plants were used for this study. The nitrogen treatments were applied 20 DAPr (Days after Pruning) when the sprouting of mulberry plant was started and other cultural practices like irrigation, digging cum weeding, insect-pest management practices etc. were done as per requirement. Each plot size was $4.60 \times 3.70 \mathrm{~m}$, plant-plant distance $0.92 \mathrm{~m}$ and line-line distance $0.92 \mathrm{~m}$.

\section{Experimental Design and Treatments}

Experiment was conducted in split plot design with three replications and the respective nitrogen treatments were applied in the assign split plots.

The following $\mathrm{N}$ treatments were applied in the experimental plots:

$\mathrm{T}_{0}$ : Only the BSRTI recommended basal dose of $\mathrm{P}$ and $\mathrm{K}$ were applied no $\mathrm{N}$ was applied $(150 \mathrm{~kg} \mathrm{P}$ and $\mathrm{K}=$ $100 \mathrm{~kg} / \mathrm{ha} / \mathrm{yr}$ ).
$\mathrm{T}_{1}: 80 \mathrm{~kg} \mathrm{~N}+\mathrm{BSRTI}$ recommended basal dose of $\mathrm{P}$ and $\mathrm{K}$ per hectare per year.

$\mathrm{T}_{2}: 160 \mathrm{~kg} \mathrm{~N}+\mathrm{BSRTI}$ recommended basal dose of $\mathrm{P}$ and $\mathrm{K}$ per hectare per year.

$\mathrm{T}_{3}: 240 \mathrm{~kg} \mathrm{~N}+\mathrm{BSRTI}$ recommended basal dose of $\mathrm{P}$ and $\mathrm{K}$ per hectare per year.

$\mathrm{T}_{4}: 320 \mathrm{~kg} \mathrm{~N}+$ BSRTI recommended basal dose of $\mathrm{P}$ and $\mathrm{K}$ per hectare per year.

$\mathrm{T}_{5}: 400 \mathrm{~kg} \mathrm{~N}+$ BSRTI recommended basal dose of $\mathrm{P}$ and $\mathrm{K}$ per hectare per year.

\section{E. Measurement of Soil Physical and Chemical Properties}

The soil $\mathrm{pH}$ was determined in deionizer water using a soil: water ratio of $1: 5$ by using the glass electrode method [16]. Soil organic $\mathrm{C}$ was determined by chromic acid digestion and spectrophotometric analysis [17]. Soil organic matter content was determined by multiplying the percent value of organic carbon with the conventional Van-Bemmelen's factor of 1.724 [18]. The nitrogen content of the soil sample was determined by distilling soil with alkaline potassium permanganate solution [19]. The distillate was collected in 20 $\mathrm{ml}$ of $2 \%$ boric acid solution with methylred and bromocresol green indicator and titrated with $0.02 \mathrm{~N}$ sulphuric acid $\left(\mathrm{H}_{2} \mathrm{SO}_{4}\right)$ [20]. Soil available $\mathrm{S}$ (ppm) was determined by calcium phosphate extraction method with a spectrophotometer at $535 \mathrm{~nm}$ [21]. The soil available K was extracted with $1 \mathrm{~N} \mathrm{NH}_{4} \mathrm{OAC}$ and determined by an atomic absorption spectrometer [22]. The available $\mathrm{P}$ of the soil was determined by spectrophotometer at a wavelength of $890 \mathrm{~nm}$. The soil sample was extracted by Olsen method with $0.5 \mathrm{M}$ $\mathrm{NaHCO}_{3}$ as outlined by [23]. Zn in the soil sample was measured by an atomic absorption spectrophotometer (AAS) after extracting with DTPA [24].

\section{F. Recorded Growth and Yield Parameters}

Growth attributes namely, node per meter, length of longest shoot per plant, total branch number per plant, total branch height per plant $(\mathrm{cm})$, total shoot weight per plant $(\mathrm{g})$, 10 leaf area per plant $\left(\mathrm{cm}^{2}\right), 10$ leaf weight per plant $(\mathrm{gm})$ and total leaf yield/ha/year (Mt) were recorded crop wise. Data were collected at 90 DAPr for each cropping seasons i.e., four times data was collected in a year and the annual yield was computed by pooling the two years data.

\section{G. Analysis of Leaf Quality Parameters}

The mulberry leaf samples at different heights of the plant (top, middle and bottom) were collected in paper bags at $75 \mathrm{~d}$ after pruning and composite leaf samples were made. Then the leaves sample were shade dried for three days and again then dried in hot air oven at $700{ }^{\circ} \mathrm{C}$ for one hour and were ground into powder for chemo-assay. The moisture (\%) was determined followed by [25].Chlorophyll-a and Chlorophyllb content were estimated following the procedure outlined by Hiscox \& Israelstam [26] using the spectrophotometer and were computed using the standard formulae [27], total mineral $(\%)$ followed [28], protein $(\%)$ followed by the Kjeldahl's method [29],total sugar and reducing sugar (\%) followed by the Miller [30] and [31] procedure and methods and soluble carbohydrate (\%) followed by [32] method. Nitrogen, phosphorus, and potassium contents in leaf were 
analyzed as per the standard procedures [33] and ultimately the uptake of these nutrients was calculated.

\section{H. Analysis of Diseases Data}

For a period of two consecutive years in each replication 10 mulberry plants were taken into observation to study the incidence of respective diseases and data were collected at 60 days after pruning. Disease incidence (\%) was assessed as number of total mulberry leaves per plant was infected by powdery mildew, leaf spot, leaf rust and tukra diseases with any visible symptom of respective disease. The percentage of disease incidence (PDI) was calculated using the formula of Rai and Mamatha[34] which was following:

$$
\begin{gathered}
\text { Percent Disease Incidence (PDI) }= \\
\frac{\text { Numberoftotalleavesoneach plant }}{\text { Numberofdiseasedleavesoneach plant }} \times 100
\end{gathered}
$$

\section{Silkworm Rearing}

Silkworm rearing was conducted four seasons in a year. For each treatment one egg laying was reared and three replications were maintained. After III molts about 100 larvae/replication was maintained. Larvae were feed four times daily (6 am, $10 \mathrm{am}, 4 \mathrm{pm}$ and $10 \mathrm{pm}$ ) with healthy fresh mulberry leaves. Young age larvae were fed with tender, succulent leaves while mature and coarse leaves were fed to larvae when they grow till ripening. Cocoons were collected on $5^{\text {th }}$ day of mounting and were assessed for commercial parameters viz: Weight. of 10 matured larval (g), Effective rate of rearing by number, Single cocoon weight. (g), Single shell weight (g), SR\%, highest filament length (m), Rendita and Yield/100dfls (kg). Methods described by Wong [29] were followed for the assessment of cocoon quality.

\section{J. Statistical Analysis}

The growth and yield contributing data were analyzed by using the Genstat $12.1^{\text {th }} \mathrm{ed}^{\mathrm{n}}$ for Windows (Lawes Agricultural Trust, UK) and one-way ANOVA was performed to detect differences for each parameter among the treatments. Sigma Plot 12.5 versions was used for representing the results as a figure form. The leaf quality, nutrient uptake and diseases data were statistically analyzed, and mean values were evaluated by DMRT test through using the Statistic-10 software. In case of soil the mean values of post-harvest soil properties were recorded for this study.

\section{RESULTS}

\section{A. Effect of Nitrogen on Post-harvest Soil Properties of the Experimental Soil}

The average physicochemical properties of the postharvest experimental soil are presented in (see Table I). The average soil $\mathrm{pH}, \mathrm{OM}, \mathrm{N}, \mathrm{P}, \mathrm{K}, \mathrm{Zn}, \mathrm{Ca}$ and $\mathrm{Mg}$ for (0-5) year's plant was 7.6 to $8.1,1.23$ to $1.63 \%, 0.06$ to $0.09 \%, 9.9$ to 13.3 micro g/g, 0.13 to $0.22 \mathrm{meq} / 100 \mathrm{~g}$ soil, 0.49 to $0.57 \mathrm{micro} \mathrm{g} / \mathrm{g}$, 17.18 to $17.28 \mathrm{meq} / 100 \mathrm{~g}$ soil and 227 to $2.53 \mathrm{meq} / 100 \mathrm{~g}$ soil respectively. On the other hand, the average soil $\mathrm{pH}, \mathrm{OM}, \mathrm{N}$, $\mathrm{P}, \mathrm{K}, \mathrm{Zn}, \mathrm{Ca}$, and $\mathrm{Mg}$ for (6-10) year's plant were 7.5 to 8.1, 1.25 to $1.65 \%, 0.06$ to $0.10 \%, 9.9$ to $13.5 \mathrm{micro} \mathrm{g} / \mathrm{g}, 0.13$ to $0.22 \mathrm{meq} / 100 \mathrm{~g}$ soil, 0.50 to $0.59 \mathrm{micro} \mathrm{g} / \mathrm{g}, 17.17$ to
$17.29 \mathrm{meq} / 100 \mathrm{~g}$ soil and 2.29 to $2.51 \mathrm{meq} / 100 \mathrm{~g}$ soil respectively.

\section{B. Growth Response of Mulberry Plant due to Ages and nitrogen Levels}

The node per meter of older leaf was significantly $(P<$ $0.001)$ higher than the younger leaf of mulberry plant. Among the six fertilizer treatments the treatment $\mathrm{T}_{5}\left(\mathrm{~N}_{400} \mathrm{P}_{150} \mathrm{~K}_{100}\right.$ $\mathrm{kg} / \mathrm{ha} / \mathrm{yr}$ ) exhibited statistically the highest number of nodes in both the older (6-10 years) and younger ( $<5$ years) mulberry plants. But their interactive effect between plant age and $\mathrm{N}_{2}$ fertilizer was not significantly different (see Table II; Fig. 1). However, among the two types of mulberry plant the maximum node per meter 34.30 was found for (6-10) year's plant.

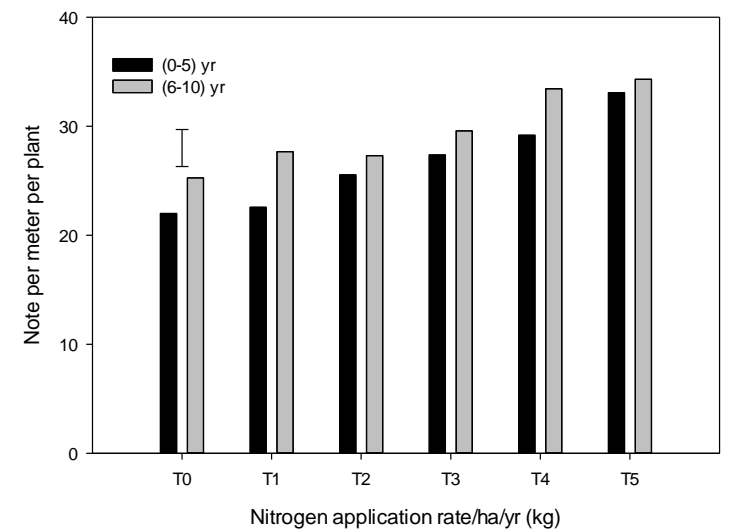

Fig. 1. Node per meter in mulberry plants as influenced by various levels of $\mathrm{N}$ management practices. Where, $\mathrm{T}_{0}=0 \mathrm{~kg} \mathrm{~N} / \mathrm{ha} / \mathrm{yr}, \mathrm{T}_{1}=80 \mathrm{~kg} \mathrm{~N} / \mathrm{ha} / \mathrm{yr}$,

$\mathrm{T}_{2}=160 \mathrm{~kg} \mathrm{~N} / \mathrm{ha} / \mathrm{yr}, \mathrm{T}_{3}=240 \mathrm{~kg} \mathrm{~N} / \mathrm{ha} / \mathrm{yr}, \mathrm{T}_{4}=320 \mathrm{~kg} \mathrm{~N} / \mathrm{ha} / \mathrm{yr}$ and $\mathrm{T}_{5}=400 \mathrm{~kg} \mathrm{~N} / \mathrm{ha} / \mathrm{yr}$. Vertical bar represent LSD $(P=0.05)$ different levels of nitrogen and mulberry plant age interactions.

Total branch per plant was statistically $(P<0.001)$ differ between the younger and older mulberry plant. The treatment $\mathrm{T}_{5}\left(\mathrm{~N}_{400} \mathrm{P}_{150} \mathrm{~K}_{100} \mathrm{~kg} / \mathrm{ha} / \mathrm{yr}\right)$ showed the significant number of total branches per plant in both the older and younger mulberry plant as compared to the other treatments. But their interactive effect (Age $\times$ Treatment) was not significantly differing (see Table II; Fig. 2). Among the younger and older mulberry plant, the maximum total branch number/plant was obtained (16.67) in older (6-10 years) mulberry plant.

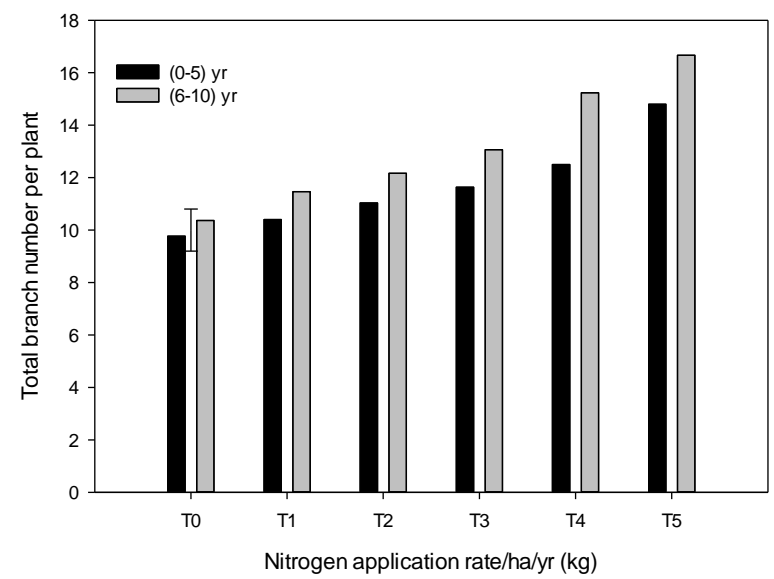

Fig. 2. Total numbers of branches per plant in mulberry as influenced by various levels of $\mathrm{N}$ management practices. Where, $\mathrm{T}_{0}=0 \mathrm{~kg} \mathrm{~N} / \mathrm{ha} / \mathrm{yr}$, $\mathrm{T}_{1}=80 \mathrm{~kg} \mathrm{~N} / \mathrm{ha} / \mathrm{yr}, \mathrm{T}_{2}=160 \mathrm{~kg} \mathrm{~N} / \mathrm{ha} / \mathrm{yr}, \mathrm{T}_{3}=240 \mathrm{~kg} \mathrm{~N} / \mathrm{ha} / \mathrm{yr}$, $\mathrm{T}_{4}=320 \mathrm{~kg} \mathrm{~N} / \mathrm{ha} / \mathrm{yr}$ and $\mathrm{T}_{5}=400 \mathrm{~kg} \mathrm{~N} / \mathrm{ha} / \mathrm{yr}$. Vertical bar represent LSD $(P=0.05)$ different levels of nitrogen and mulberry plant age interactions. 
The total length of branches per plant differed significantly for nitrogen treatment $(\mathrm{P} \leq 0.001)$, plant types $(\mathrm{P} \leq 0.001)$ and also the interactive effect of (Age $\times$ Treatment $)(\mathrm{P} \leq 0.01)$. Between the two types of plant the average maximum total branch height per plant was $1145.67 \mathrm{~cm}$ in (6-10) year's plant for $\mathrm{T}_{5}$ treatment and the average minimum height was $1079.61 \mathrm{~cm}$ in (0-5) year's plant for control treatment (see Table II; Fig. 3).

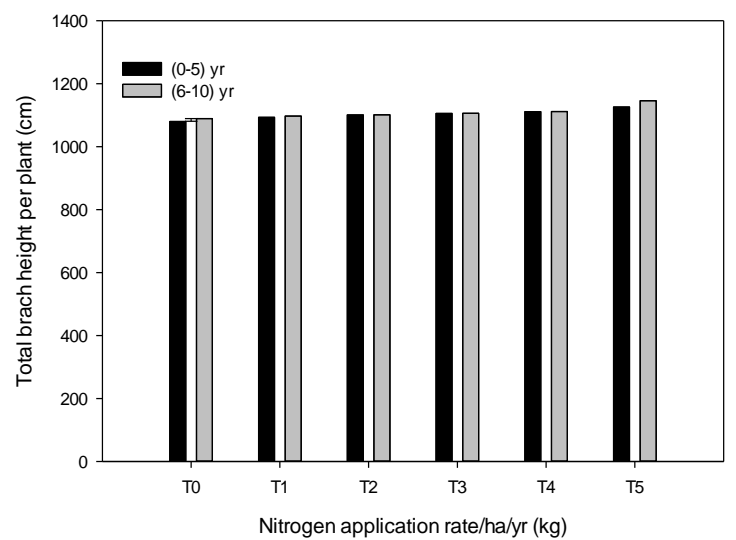

Fig. 3. Total branch length per plant in mulberry as influenced by various levels of $\mathrm{N}$ management practices. Where, $\mathrm{T}_{0}=0 \mathrm{~kg} \mathrm{~N} / \mathrm{ha} / \mathrm{yr}, \mathrm{T}_{1}=80 \mathrm{~kg}$ $\mathrm{N} / \mathrm{ha} / \mathrm{yr}, \mathrm{T}_{2}=160 \mathrm{~kg} \mathrm{~N} / \mathrm{ha} / \mathrm{yr}, \mathrm{T}_{3}=240 \mathrm{~kg} \mathrm{~N} / \mathrm{ha} / \mathrm{yr}, \mathrm{T}_{4}=320 \mathrm{~kg} \mathrm{~N} / \mathrm{ha} / \mathrm{yr}$ and $\mathrm{T}_{5}=400 \mathrm{~kg} \mathrm{~N} / \mathrm{ha} / \mathrm{yr}$. Vertical bar represent LSD $(P=0.05)$ different levels of nitrogen and mulberry plant age interactions.

The length of longest shoot was significantly $(P<0.001)$ increased with increment of the rate of $\mathrm{N}$ application in the mulberry plant. Among the six doses of nitrogen the average maximum length of shoot was found for the treatment of $\mathrm{T}_{5}$ $\left(\mathrm{N}_{400} \mathrm{P}_{150} \mathrm{~K}_{100} \mathrm{~kg} / \mathrm{ha} / \mathrm{yr}\right)$ than the other treatments. There was no significant difference between the plant types and the interactive effect (Age $\times$ Treatment) (see Table II; Fig. 4). However, between the two types of mulberry plant the maximum average length of shoot was $168.32 \mathrm{~cm}^{2}$ for older (6-10) and minimum $124.55 \mathrm{~cm}$ for (0-5) year's mulberry plant.

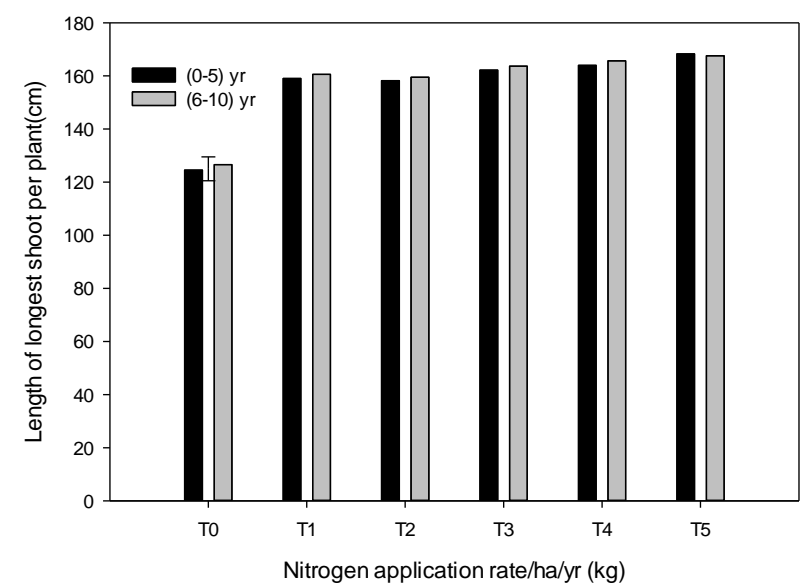

Fig. 4. Length of longest shoot per plant in mulberry as influenced by various levels of $\mathrm{N}$ management practices. Where, $\mathrm{T}_{0}=0 \mathrm{~kg} \mathrm{~N} / \mathrm{ha} / \mathrm{yr}$, $\mathrm{T}_{1}=80 \mathrm{~kg} \mathrm{~N} / \mathrm{ha} / \mathrm{yr}, \mathrm{T}_{2}=160 \mathrm{~kg} \mathrm{~N} / \mathrm{ha} / \mathrm{yr}, \mathrm{T}_{3}=240 \mathrm{~kg} \mathrm{~N} / \mathrm{ha} / \mathrm{yr}$,

$\mathrm{T}_{4}=320 \mathrm{~kg} \mathrm{~N} / \mathrm{ha} / \mathrm{yr}$ and $\mathrm{T}_{5}=400 \mathrm{~kg} \mathrm{~N} / \mathrm{ha} / \mathrm{yr}$. Vertical bar represent LSD $(P=0.05)$ different levels of nitrogen and mulberry plant age interactions.

The total shoot weight per plant was not significantly differed both for the ages of mulberry plant and the interactive effect (Age $\times$ Treatment) (see Table II; Fig. 5).
The average maximum total shoot weight was $828.38 \mathrm{~g}$ for $\mathrm{T}_{5}\left(\mathrm{~N}_{400} \mathrm{P}_{150} \mathrm{~K}_{100} \mathrm{~kg} / \mathrm{ha} / \mathrm{yr}\right)$ treatment which was statistically $(P \leq 0.001)$ greater than those of other treatments. The minimum total shoot weight was $756.36 \mathrm{~g}$ in $(6-10)$ year's plant for control treatment.

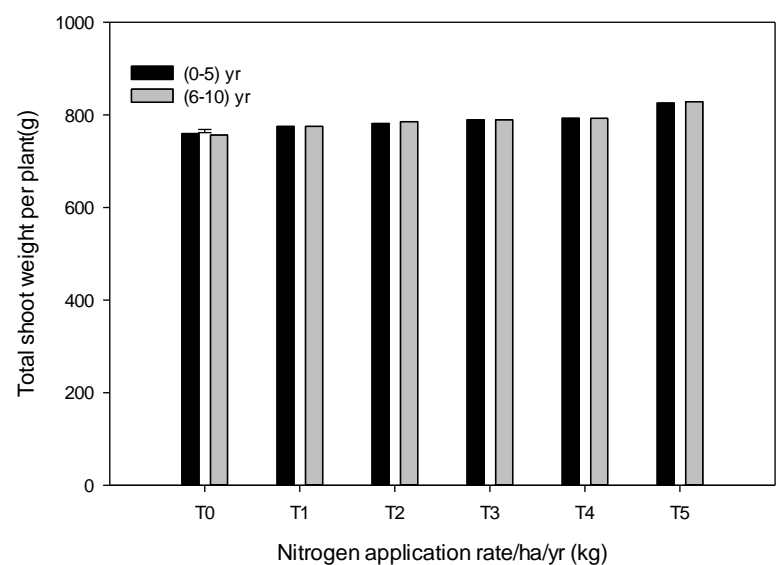

Fig. 5. Total shoot weight per plant in mulberry as influenced by various levels of $\mathrm{N}$ management practices. Where, $\mathrm{T}_{0}=0 \mathrm{~kg} \mathrm{~N} / \mathrm{ha} / \mathrm{yr}$, $\mathrm{T}_{1}=80 \mathrm{~kg} \mathrm{~N} / \mathrm{ha} / \mathrm{yr}, \mathrm{T}_{2}=160 \mathrm{~kg} \mathrm{~N} / \mathrm{ha} / \mathrm{yr}, \mathrm{T}_{3}=240 \mathrm{~kg} \mathrm{~N} / \mathrm{ha} / \mathrm{yr}$, $\mathrm{T}_{4}=320 \mathrm{~kg} \mathrm{~N} / \mathrm{ha} / \mathrm{yr}$ and $\mathrm{T}_{5}=400 \mathrm{~kg} \mathrm{~N} / \mathrm{ha} / \mathrm{yr}$. Vertical bar represent LSD $(P=0.05)$ different levels of nitrogen and mulberry plant age interactions.

The mean leaf area of 10 leaves of older mulberry plant was significantly $(P<0.05)$ affected by $\mathrm{N}$ application than the younger mulberry plant. The treatment $\mathrm{T}_{5}\left(\mathrm{~N}_{400} \mathrm{P}_{150} \mathrm{~K}_{100}\right.$ $\mathrm{kg} / \mathrm{ha} / \mathrm{yr}$ ) showed the highest mean leaf area both for the older and younger mulberry leaf than the other $\mathrm{N}$ treatments. But their interactive effect (Age $\times$ Treatment) did not differ significantly both for the younger and older mulberry plant (see Table II; Fig. 6). However, among the two types of mulberry plant the maximum mean leaf area of $743.74 \mathrm{~cm}^{2}$ was found for older (6-10) mulberry leaf.

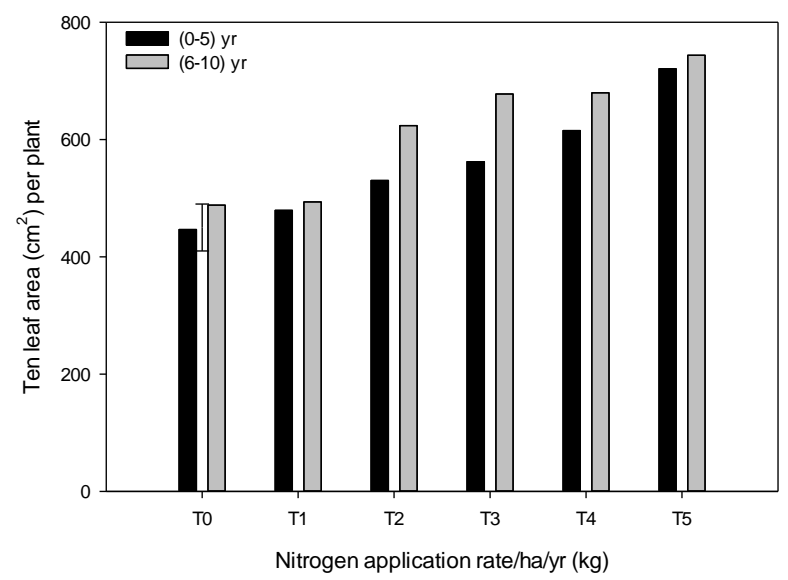

Fig. 6. 10 leaf area per plant in mulberry as influenced by various levels of $\mathrm{N}$ management practices. Where, $\mathrm{T}_{0}=0 \mathrm{~kg} \mathrm{~N} / \mathrm{ha} / \mathrm{yr}, \mathrm{T}_{1}=80 \mathrm{~kg} \mathrm{~N} / \mathrm{ha} / \mathrm{yr}$,

$\mathrm{T}_{2}=160 \mathrm{~kg} \mathrm{~N} / \mathrm{ha} / \mathrm{yr}, \mathrm{T}_{3}=240 \mathrm{~kg} \mathrm{~N} / \mathrm{ha} / \mathrm{yr}, \mathrm{T}_{4}=320 \mathrm{~kg} \mathrm{~N} / \mathrm{ha} / \mathrm{yr}$ and $\mathrm{T}_{5}=400 \mathrm{~kg} \mathrm{~N} / \mathrm{ha} / \mathrm{yr}$. Vertical bar represent LSD $(P=0.05)$ different levels of nitrogen and mulberry plant age interactions.

The weight of 10 leaves per plant varied significantly $(P<$ $0.05)$ for the older mulberry plant than the younger mulberry plant. Among the six $\mathrm{N}_{2}$ fertilizer treatments the treatment $\mathrm{T}_{5}$ $\left(\mathrm{N}_{400} \mathrm{P}_{150} \mathrm{~K}_{100} \mathrm{~kg} / \mathrm{ha} / \mathrm{yr}\right)$ was significantly $(P<0.001)$ higher both for the older and younger mulberry plant. The interactive effect of mulberry plant age and $\mathrm{N}$ fertilizer treatment was not statistically different (see Table II; Fig. 7). The maximum 
weight of 10 leaves $50.37 \mathrm{~g}$ was recorded in older (6-10 years) mulberry plant and in case of (0-5) years mulberry plant the highest 10 leaf weight per plant was $47.40 \mathrm{gm}$.

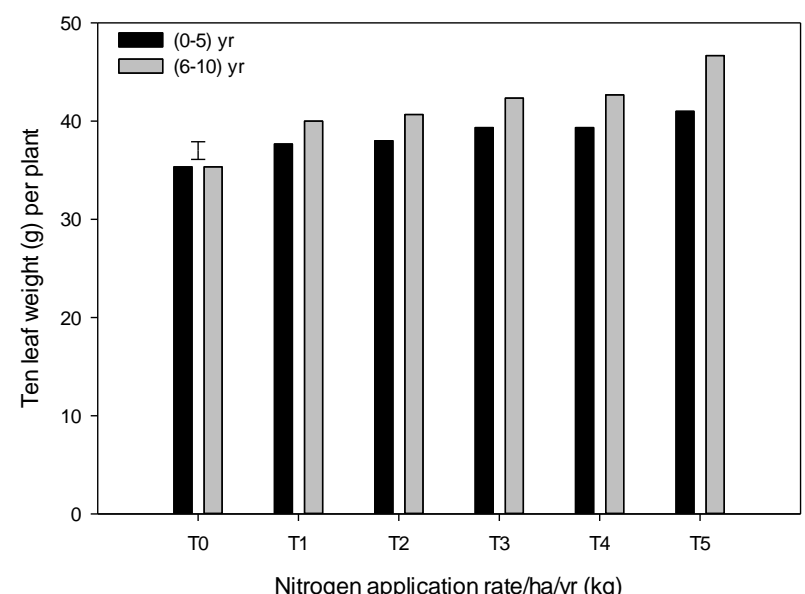

Fig. 7. Weight of 10 leaves per plant in mulberry as influenced by various levels of $\mathrm{N}$ management practices. Where, $\mathrm{T}_{0}=0 \mathrm{~kg} \mathrm{~N} / \mathrm{ha} / \mathrm{yr}$, $\mathrm{T}_{1}=80 \mathrm{~kg} \mathrm{~N} / \mathrm{ha} / \mathrm{yr}, \mathrm{T}_{2}=160 \mathrm{~kg} \mathrm{~N} / \mathrm{ha} / \mathrm{yr}, \mathrm{T}_{3}=240 \mathrm{~kg} \mathrm{~N} / \mathrm{ha} / \mathrm{yr}$, $\mathrm{T}_{4}=320 \mathrm{~kg} \mathrm{~N} / \mathrm{ha} / \mathrm{yr}$ and $\mathrm{T}_{5}=400 \mathrm{~kg} \mathrm{~N} / \mathrm{ha} / \mathrm{yr}$. Vertical bars represent LSD $(P=0.05)$ different levels of nitrogen and mulberry plant age interaction.

The total leaf yield of mulberry plants increased significantly with increased rate of $\mathrm{N}$ application up to the highest level $\left(\mathrm{N}_{400} \mathrm{P}_{150} \mathrm{~K}_{100} \mathrm{~kg} / \mathrm{ha} / \mathrm{yr}\right.$ ) in $\mathrm{T}_{5}$ treatment (see Table II; Fig. 8). The highest leaf yield of $51.88 \mathrm{mt} / \mathrm{ha} / \mathrm{yr}$ was recorded in $\mathrm{T}_{5}$ treatment from older (6-10 years) mulberry plants. Under each treatment the older plants (6-10 years) gave higher leaf yield as compared to the younger ( $0-5$ years) mulberry plants.

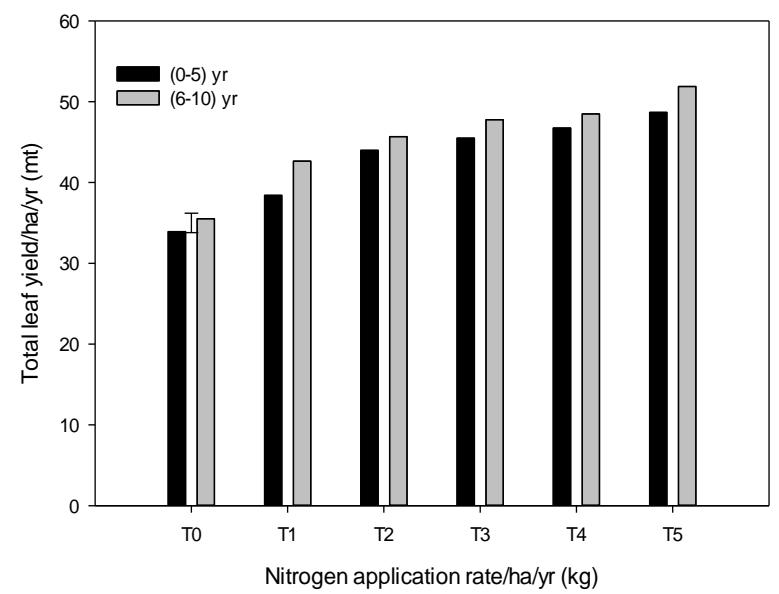

Fig. 8. Total leaf yield/ha/year in mulberry as influenced by various levels of $\mathrm{N}$ management practices. Where, $\mathrm{T}_{0}=0 \mathrm{~kg} \mathrm{~N} / \mathrm{ha} / \mathrm{yr}, \mathrm{T}_{1}=80 \mathrm{~kg} \mathrm{~N} / \mathrm{ha} / \mathrm{yr}$, $\mathrm{T}_{2}=160 \mathrm{~kg} \mathrm{~N} / \mathrm{ha} / \mathrm{yr}, \mathrm{T}_{3}=240 \mathrm{~kg} \mathrm{~N} / \mathrm{ha} / \mathrm{yr}, \mathrm{T}_{4}=320 \mathrm{~kg} \mathrm{~N} / \mathrm{ha} / \mathrm{yr}$ and $\mathrm{T}_{5}=$ $400 \mathrm{~kg} \mathrm{~N} / \mathrm{ha} / \mathrm{yr}$. Vertical bar represent LSD $(P=0.05)$ different levels of nitrogen and mulberry plant age interactions.

\section{Effect of Ages of Mulberry Plant and Nitrogen Levels on Leaf Quality of Mulberry Plant}

The moisture $(\%)$ of mulberry leaves was significantly changed due to the plant ages and $\mathrm{N}_{2}$ fertilizer treatment. Among the six fertilizer treatments the maximum moisture (\%) 78.59 was found in (6-10) year's plant for the treatment of $\mathrm{T}_{5}\left(\mathrm{~N}_{400} \mathrm{P}_{150} \mathrm{~K}_{100} \mathrm{~kg} / \mathrm{ha} / \mathrm{yr}\right)$. On the hand minimum moisture (\%) 67.78 was obtained in $(0-5)$ year's mulberry plant for the treatment of $\mathrm{T}_{0}$ (see Table III).
The Chlorophyll-a content in mulberry leaves was statistically varied due to the plant ages and $\mathrm{N}_{2}$ fertilizer treatment. The maximum Chlorophyll-a 5.41 micro g was recorded in (6-10) year's plant for the treatment of $\mathrm{T}_{5}$ and the minimum Chlorophyll-a content was 1.07 micro g in (0-5) year's plant for the treatment of $\mathrm{T}_{0}$. The plant ages and $\mathrm{N}_{2}$ fertilizer treatment significantly changed the Chlorophyll-b content in mulberry leaves. Among the six fertilizer treatments the maximum Chlorophyll-b 59.23 micro g was recorded in (6-10) years mulberry plant for the treatment of $\mathrm{T}_{5}\left(\mathrm{~N}_{400} \mathrm{P}_{150} \mathrm{~K}_{100} \mathrm{~kg} / \mathrm{ha} / \mathrm{yr}\right)$. On the other hand, the minimum Chlorophyll-b 45.73 micro g was recorded also in (6-10) years mulberry plant for the treatment of $\mathrm{T}_{3}$ (see Table III).

The reducing sugar $(\%)$ in mulberry leaf was not statistically differing both for the plant ages and $\mathrm{N}_{2}$ fertilizer treatment. However, the maximum reducing sugar $4.09 \%$ was recorded in (6-10) years plant for the treatment of $\mathrm{T}_{5}\left(\mathrm{~N}_{400}\right.$ $\mathrm{P}_{150} \mathrm{~K}_{100} \mathrm{~kg} / \mathrm{ha} / \mathrm{yr}$ ) which was statistically similar with the treatments of $\mathrm{T}_{2}, \mathrm{~T}_{3}$ and $\mathrm{T}_{4}$ (see Table III).

The plant ages and $\mathrm{N}_{2}$ fertilizer treatment significantly changed the total mineral content in mulberry leaves. The maximum total mineral $11.37 \%$ was recorded in the leaf of (6-10) year plant for the treatment of $\mathrm{T}_{5}\left(\mathrm{~N}_{400} \mathrm{P}_{150} \mathrm{~K}_{100}\right.$ $\mathrm{kg} / \mathrm{ha} / \mathrm{yr}$ ) which was statistically similar with the leaf of (0-5) year's plant. However, the minimum total mineral $8.81 \%$ was recorded in (0-5) year plant for the treatment of $\mathrm{T}_{0}$. The total sugar content in mulberry leaves were considerably increased due to the plant ages and $\mathrm{N}_{2}$ fertilizer treatment. The maximum total sugar $6.51 \%$ was recorded in the leaf of (610) year plant for the treatment of $T_{5}$ On the other hand the minimum total sugar $4.75 \%$ was recorded in (0-5) year's plant for the treatment of $\mathrm{T}_{0}$. Similarly, soluble carbohydrate content in mulberry leaves was significantly greater due to the plant age but not statistically differ due to the $\mathrm{N}_{2}$ treatment. The maximum soluble carbohydrate $10.44 \%$ was recorded in the leaf of (6-10) year plant for the treatment of $\mathrm{T}_{5}\left(\mathrm{~N}_{400} \mathrm{P}_{150} \mathrm{~K}_{100} \mathrm{~kg} / \mathrm{ha} / \mathrm{yr}\right)$ which were statistically similar with the treatments of $\mathrm{T}_{3}$ and $\mathrm{T}_{4}$. However, the minimum soluble carbohydrate $7.44 \%$ was recorded in (0-5) year's plant for the treatment of $\mathrm{T}_{0}$ (see Table III).

The age and $\mathrm{N}_{2}$ fertilizer treatment was significantly affected the crude protein content in mulberry leaves. The maximum crude protein $23.22 \%$ was recorded in the leaf of (6-10) year's plant for the treatment of $\mathrm{T}_{5}\left(\mathrm{~N}_{400} \mathrm{P}_{150} \mathrm{~K}_{100}\right.$ $\mathrm{kg} / \mathrm{ha} / \mathrm{yr})$ which was statistically similar with the leaves of (05 ) year's plant. On the other hand, the minimum crude protein $16.14 \%$ was recorded in the leaf of (0-5) year's plant for the treatment of $\mathrm{T}_{0}$ (see Table III).

\section{Impact of Nitrogen on Suppression of Common Diseases in Mulberry Leaf}

The infestation of tukra, powdery mildew and leaf spot diseases in (6-10) year's mulberry plant were significantly varied due to the gradated doses of soil applied nitrogen. The average incidence percentage of tukra, leaf spot and powdery mildew diseases were comparatively low due to the elevated doses of nitrogen. In case of powdery mildew and leaf spot the average lower incidence, percentages were 1.08 and 0.61 , respectively for the treatment of $\mathrm{T}_{4}\left(\mathrm{~N}_{320} \mathrm{P}_{150} \mathrm{~K}_{100} \mathrm{~kg} / \mathrm{ha} / \mathrm{yr}\right)$. But the lower average incidence percentage of tukra was 1.36 for the treatment $\mathrm{T}_{5}\left(\mathrm{~N}_{400} \mathrm{P}_{150} \mathrm{~K}_{100} \mathrm{~kg} / \mathrm{ha} / \mathrm{yr}\right)$. However, the average incidences percentages of all the three diseases viz: powdery mildew, leaf 
spot and tukra were comparatively maximum for the control treatment than the other treatments (see Table IV).

\section{E. Effect of Different Levels of Nitrogen Treated Mulberry Leaves on Silkworm Rearing Performance}

The silkworm rearing performance as well as silk cocoon productivity was significantly differed due to the feeding of different levels of $\mathrm{N}$ applied mulberry leaves in (6-10 years) ages of mulberry plant. The average maximum wt. of 10 matured larval $(\mathrm{g})$, effective rate of rearing by number, single cocoon wt. (g), single shell wt. (g), SR\%, highest filament length $(\mathrm{m})$ and silk cocoon yield/100dfls (kg)were 36.97, $9330,1.62,0.28,18.49,1011.40$ and 79.13 , respectively and the average lowest rendita (how much $\mathrm{kg}$ raw cocoon is needed for getting of $1 \mathrm{~kg}$ raw silk) was 10.03 (see Table V) for feeding of $\mathrm{T}_{5}\left(\mathrm{~N}_{400} \mathrm{P}_{150} \mathrm{~K}_{100} \mathrm{~kg} / \mathrm{ha} / \mathrm{yr}\right)$ treated mulberry leaves.

TABLE I: EFFECT OF NitROGEN LEVELS ON PHYSICOCHEMICAL PROPERTIES OF THE POST-HARVEST EXPERIMENTAL SOIL

\begin{tabular}{|c|c|c|c|c|c|c|c|c|c|c|c|c|c|c|c|c|}
\hline \multirow{3}{*}{ 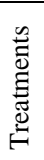 } & \multirow{2}{*}{\multicolumn{2}{|c|}{$\begin{array}{l}\text { Soil pH } \\
\text { Plant age }\end{array}$}} & \multicolumn{2}{|c|}{ OM (\%) } & \multicolumn{2}{|c|}{$\mathrm{N}(\%)$} & \multicolumn{2}{|c|}{$\mathrm{P}$ (micro g/g) } & \multicolumn{2}{|c|}{$\begin{array}{l}\mathrm{K}(\mathrm{meq} / 100 \mathrm{~g} \\
\text { soil) }\end{array}$} & \multicolumn{2}{|c|}{ Zn (micro g/g) } & \multicolumn{2}{|c|}{$\begin{array}{c}\mathrm{Ca}(\mathrm{meq} / 100 \mathrm{~g} \\
\text { soil) }\end{array}$} & \multicolumn{2}{|c|}{$\begin{array}{c}\mathrm{Mg}(\mathrm{meq} / 100 \mathrm{~g} \\
\text { soil })\end{array}$} \\
\hline & & & & age & Pla & age & & age & & age & & age & & age & & age \\
\hline & $(0-5)$ & $(6-10)$ & $(0-5)$ & $(6-10)$ & $(0-5)$ & $(6-10)$ & $(0-5)$ & $(6-10)$ & $(0-5)$ & $(6-10)$ & $(0-5)$ & $(6-10)$ & $(0-5)$ & $(6-10)$ & $(0-5)$ & $(6-10)$ \\
\hline $\mathrm{T}_{0}$ & 8.1 & 8.3 & 1.57 & 1.59 & 0.09 & 0.10 & 6.3 & 6.4 & 0.18 & 0.17 & 0.76 & 0.77 & 17.51 & 17.49 & 2.29 & 2.31 \\
\hline $\mathrm{T}_{1}$ & 7.9 & 8.0 & 1.68 & 1.67 & 0.07 & 0.08 & 8.9 & 8.8 & 0.18 & 0.18 & 0.68 & 0.67 & 17.83 & 17.85 & 2.33 & 2.34 \\
\hline $\mathrm{T}_{2}$ & 7.5 & 7.4 & 1.46 & 1.47 & 0.08 & 0.09 & 8.7 & 8.6 & 0.16 & 0.17 & 0.65 & 0.66 & 17.86 & 17.87 & 2.39 & 2.41 \\
\hline $\mathrm{T}_{3}$ & 7.3 & 7.2 & 1.48 & 1.5 & 0.07 & 0.08 & 8.8 & 8.7 & 0.15 & 0.17 & 0.63 & 10.64 & 17.78 & 17.83 & 2.46 & 2.47 \\
\hline $\mathrm{T}_{4}$ & 6.9 & 6.7 & 1.55 & 1.53 & 0.09 & 0.08 & 8.6 & 8.8 & 0.17 & 0.16 & 0.66 & 0.67 & 17.73 & 17.72 & 2.56 & 2.59 \\
\hline $\mathrm{T}_{5}$ & 6.7 & 6.6 & 1.65 & 1.67 & 0.10 & 0.11 & 8.4 & 8.8 & 0.18 & 0.17 & 0.67 & 0.65 & 17.92 & 17.95 & 2.79 & 2.82 \\
\hline
\end{tabular}

Here, $\mathrm{T}_{0}=\mathrm{N}_{0} \mathrm{P}_{150} \mathrm{~K}_{100} \mathrm{~kg} / \mathrm{ha} / \mathrm{yr}, \mathrm{T}_{1}=\mathrm{N}_{80} \mathrm{P}_{150} \mathrm{~K}_{100} \mathrm{~kg} / \mathrm{ha} / \mathrm{yr}, \mathrm{T}_{2}=\mathrm{N}_{160} \mathrm{P}_{150} \mathrm{~K}_{100} \mathrm{~kg} / \mathrm{ha} / \mathrm{yr}, \mathrm{T}_{3}=\mathrm{N}_{240} \mathrm{P}_{150} \mathrm{~K}_{100} \mathrm{~kg} / \mathrm{ha} / \mathrm{yr}, \mathrm{T}_{4}=\mathrm{N}_{320} \mathrm{P}_{150} \mathrm{~K}_{100} \mathrm{~kg} / \mathrm{ha} / \mathrm{yr}$ and T $\mathrm{T}_{5}=\mathrm{N}_{400} \mathrm{P}_{150}$ $\mathrm{K}_{100} \mathrm{~kg} / \mathrm{ha} / \mathrm{yr}$.

TABLE II: EFFECT OF DIFFERENT LEVELS OF NITROGEN ON MULBERRY PLANT PRODUCTION

\begin{tabular}{|c|c|c|c|c|c|c|c|c|}
\hline Factors & Node/Meter & $\begin{array}{l}\text { Total branch } \\
\text { number/plant }\end{array}$ & $\begin{array}{c}\text { Length of } \\
\text { longest } \\
\text { shoot/plant } \\
(\mathrm{cm})\end{array}$ & $\begin{array}{l}\text { Total branch } \\
\text { height/plant } \\
\quad(\mathrm{cm})\end{array}$ & $\begin{array}{c}\text { Total shoot } \\
\text { weight/plant } \\
\text { (g) }\end{array}$ & $\begin{array}{l}10 \text { Leaf } \\
\text { Area/plant } \\
\left(\mathrm{cm}^{2}\right)\end{array}$ & $\begin{array}{c}10 \text { Leaf } \\
\text { weight/plant } \\
(\mathrm{g})\end{array}$ & $\begin{array}{c}\text { Total Leaf Yield } \\
(\mathrm{mt} / \mathrm{ha} / \mathrm{yr})\end{array}$ \\
\hline Treatments & $* * *$ & $* * *$ & $* * *$ & $* * *$ & $* * *$ & $* * *$ & $* *$ & $* * *$ \\
\hline Age $\times$ Treatment & n.s. & n.s. & n.s. & $* *$ & n.s. & n.s. & n.s. & n.s. \\
\hline
\end{tabular}

Where n.s., *,** and $* * *$ represent probability of $>0.05, \leq 0.05, \leq 0.01$ and $\leq 0.001$. Values were means of three replicates.

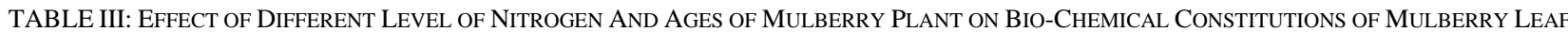

\begin{tabular}{|c|c|c|c|c|c|c|c|c|c|c|c|c|c|c|c|c|}
\hline \multirow{3}{*}{ Treatments } & \multicolumn{2}{|c|}{ Moisture (\%) } & \multicolumn{2}{|c|}{$\begin{array}{l}\text { Chlorophyll-a } \\
\text { (micro g/g) }\end{array}$} & \multicolumn{2}{|c|}{$\begin{array}{l}\text { Chlorophyll-b } \\
\text { (micro g/g) }\end{array}$} & \multicolumn{2}{|c|}{ Mineral (\%) } & \multicolumn{2}{|c|}{$\begin{array}{c}\text { Crude Protein } \\
(\%)\end{array}$} & \multicolumn{2}{|c|}{$\begin{array}{c}\text { Carbohydrate } \\
(\%)\end{array}$} & \multicolumn{2}{|c|}{$\begin{array}{l}\text { Total Sugar } \\
(\%)\end{array}$} & \multicolumn{2}{|c|}{$\begin{array}{l}\text { Reducing Sugar } \\
\qquad(\%)\end{array}$} \\
\hline & \multicolumn{2}{|c|}{ Plant age } & \multicolumn{2}{|c|}{ Plant age } & \multicolumn{2}{|c|}{ Plant age } & \multicolumn{2}{|c|}{ Plant age } & \multicolumn{2}{|c|}{ Plant age } & \multicolumn{2}{|c|}{ Plant age } & \multicolumn{2}{|c|}{ Plant age } & \multicolumn{2}{|c|}{ Plant age } \\
\hline & $(0-5)$ & 46 & $(0-5)$ & $(6-10)$ & $(0-5)$ & $(6-10$ & $-5)$ & $(6-1$ & $(0-5)$ & & $(0-5)$ & 616 & $(0-5)$ & $(6-10)$ & $-5)$ & $(6-10)$ \\
\hline $\mathrm{T}_{0}$ & $67.78 \mathrm{~g}$ & $68.96 \mathrm{f}$ & $1.07 \mathrm{~g}$ & $2.87 \mathrm{c}$ & $50.98 \mathrm{~h}$ & $45.84 \mathrm{i}$ & $81 \mathrm{e}$ & 8 & $16.14 \mathrm{i}$ & $17.07 \mathrm{~h}$ & $7.44 \mathrm{e}$ & & $4.75 \mathrm{f}$ & $4.85 \mathrm{f}$ & $3.12 \mathrm{f}$ & $3.18 \mathrm{f}$ \\
\hline $\mathrm{T}_{1}$ & $71.22 \mathrm{e}$ & $.72 \mathrm{e}$ & $1.47 \mathrm{ef}$ & $4.36 \mathrm{~b}$ & $52.3 \mathrm{f}$ & $22 \mathrm{fg}$ & $5 d$ & & 16.70hi & $59 \mathrm{~g}$ & $7.94 \mathrm{~d}$ & & $4.98 \mathrm{ef}$ & & $2 \mathrm{ef}$ & \\
\hline $\mathrm{T}_{2}$ & $82 d$ & $93 \mathrm{~d}$ & $1.41 \mathrm{ef}$ & $5.35 \mathrm{a}$ & $52.07 \mathrm{~g}$ & & $2 d$ & $3 d$ & $19.61 \mathrm{f}$ & $2 \mathrm{e}$ & $9.41 \mathrm{c}$ & $b$ & $5.19 \mathrm{de}$ & 5.4 & $9 \mathrm{ab}$ & $4.09 \mathrm{a}$ \\
\hline $\mathrm{T}_{3}$ & $74.09 \mathrm{~d}$ & $75.35 \mathrm{c}$ & $1.49 \mathrm{e}$ & $2.88 \mathrm{c}$ & $55.53 d$ & $45.73 \mathrm{i}$ & $10.51 \mathrm{c}$ & $10.62 \mathrm{c}$ & $21.75 \mathrm{~cd}$ & $22.52 b$ & $9.77 b c$ & $10.09 \mathrm{ab}$ & $5.77 \mathrm{c}$ & $5.96 \mathrm{bc}$ & $3.63 \mathrm{~cd}$ & $3.88 \mathrm{abc}$ \\
\hline $\mathrm{T}_{5}$ & $77.19 \mathrm{~b}$ & $78.59 \mathrm{a}$ & $1.37 \mathrm{f}$ & $5.41 \mathrm{a}$ & $57.73 b$ & $59.23 \mathrm{a}$ & $10.66 \mathrm{c}$ & $10.72 b c$ & $22.81 \mathrm{ab}$ & $23.22 \mathrm{a}$ & $9.92 b$ & $10.44 \mathrm{a}$ & $6.18 b$ & $6.51 \mathrm{a}$ & $3.88 \mathrm{abc}$ & $4.08 \mathrm{ab}$ \\
\hline
\end{tabular}

Means with the same letter are not significantly different at $5 \%$ level by DMRT. Here, $\mathrm{T}_{0}=\mathrm{N}_{0} \mathrm{P}_{150} \mathrm{~K}_{100} \mathrm{~kg} / \mathrm{ha} / \mathrm{yr}, \mathrm{T}_{1}=\mathrm{N}_{80} \mathrm{P}_{150} \mathrm{~K}_{100} \mathrm{~kg} / \mathrm{ha} / \mathrm{yr}, \mathrm{T}_{2}=\mathrm{N}_{160} \mathrm{P}_{150} \mathrm{~K}_{100}$ $\mathrm{kg} / \mathrm{ha} / \mathrm{yr}, \mathrm{T}_{3}=\mathrm{N}_{240} \mathrm{P}_{150} \mathrm{~K}_{100} \mathrm{~kg} / \mathrm{ha} / \mathrm{yr}, \mathrm{T}_{4}=\mathrm{N}_{320} \mathrm{P}_{150} \mathrm{~K}_{100} \mathrm{~kg} / \mathrm{ha} / \mathrm{yr}$ and $\mathrm{T}_{5}=\mathrm{N}_{400} \mathrm{P}_{150} \mathrm{~K} 100 \mathrm{~kg} / \mathrm{ha} / \mathrm{yr}$.

\begin{tabular}{|c|c|c|c|}
\hline $\mathrm{N}$ application rate $(\mathrm{kg} / \mathrm{ha} / \mathrm{yr})$ & Powdery mildew (\%) & Leaf spot $(\%)$ & Tukra (\%) \\
\hline $\mathrm{T}_{0}(0)$ & $1.54 \mathrm{a}$ & $0.84 a$ & $4.42 \mathrm{a}$ \\
\hline $\mathrm{T}_{1}(80)$ & $1.30 \mathrm{ab}$ & $0.65 a b$ & $2.45 \mathrm{ab}$ \\
\hline $\mathrm{T}_{2}(160)$ & $1.23 \mathrm{ab}$ & $0.55 b$ & $2.19 \mathrm{ab}$ \\
\hline $\mathrm{T}_{3}(240)$ & $1.30 \mathrm{ab}$ & $0.64 a b$ & $1.92 \mathrm{~b}$ \\
\hline $\mathrm{T}_{4}(320)$ & $1.08 \mathrm{~b}$ & $0.61 \mathrm{ab}$ & $2.75 \mathrm{ab}$ \\
\hline $\mathrm{T}_{5}(400)$ & $1.48 \mathrm{ab}$ & $0.67 \mathrm{ab}$ & $1.36 \mathrm{~b}$ \\
\hline
\end{tabular}

Means with the same letter are not significantly different at $5 \%$ level by DMRT. Here, $\mathrm{T}_{0}=\mathrm{N}_{0} \mathrm{P}_{150} \mathrm{~K}_{100} \mathrm{~kg} / \mathrm{ha} / \mathrm{yr}, \mathrm{T}_{1}=\mathrm{N}_{80} \mathrm{P}_{150} \mathrm{~K}_{100} \mathrm{~kg} / \mathrm{ha} / \mathrm{yr}$, $\mathrm{T}_{2}=\mathrm{N}_{160} \mathrm{P}_{150} \mathrm{~K}_{100}$ $\mathrm{kg} / \mathrm{ha} / \mathrm{yr}, \mathrm{T}_{3}=\mathrm{N}_{240} \mathrm{P}_{150} \mathrm{~K}_{100} \mathrm{~kg} / \mathrm{ha} / \mathrm{yr}, \mathrm{T}_{4}=\mathrm{N}_{320} \mathrm{P}_{150} \mathrm{~K}_{100} \mathrm{~kg} / \mathrm{ha} / \mathrm{yr}$ and $\mathrm{T}_{5}=\mathrm{N}_{400} \mathrm{P}_{150} \mathrm{~K}_{100} \mathrm{~kg} / \mathrm{ha} / \mathrm{yr}$.

\begin{tabular}{|c|c|c|c|c|c|c|c|c|}
\hline Treatments & $\begin{array}{l}\text { Wt. of } 10 \text { matured } \\
\text { larval }(\mathrm{g})\end{array}$ & $\begin{array}{l}\text { Effective rate of } \\
\text { rearing by number }\end{array}$ & $\begin{array}{c}\text { Single cocoon } \\
\text { Wt. }(\mathrm{g})\end{array}$ & $\begin{array}{l}\text { Single Shell } \\
\text { wt. (g) }\end{array}$ & $\mathrm{SR} \%$ & $\begin{array}{l}\text { Highest filament } \\
\text { length }(\mathrm{m})\end{array}$ & Rendita & $\begin{array}{c}\text { Yield/100dfls } \\
(\mathrm{kg})\end{array}$ \\
\hline $\mathrm{T}_{0}$ & $29.79 \mathrm{f}$ & $7839.90 \mathrm{f}$ & $1.29 \mathrm{e}$ & $0.19 \mathrm{~d}$ & $14.79 \mathrm{f}$ & $835.31 \mathrm{f}$ & $13.31 \mathrm{a}$ & $50.13 \mathrm{f}$ \\
\hline $\mathrm{T}_{1}$ & $30.11 \mathrm{e}$ & $7898.60 \mathrm{e}$ & $1.31 \mathrm{e}$ & $0.20 \mathrm{~cd}$ & $14.89 \mathrm{e}$ & $840.78 \mathrm{e}$ & $13.19 b$ & $51.33 \mathrm{e}$ \\
\hline $\mathrm{T}_{2}$ & $30.57 d$ & 7994.20d & $1.34 \mathrm{~d}$ & $0.22 \mathrm{c}$ & $15.11 \mathrm{~d}$ & $853.62 d$ & $13.03 \mathrm{c}$ & $51.57 \mathrm{~d}$ \\
\hline $\mathrm{T}_{3}$ & $31.17 \mathrm{c}$ & $8098.90 \mathrm{c}$ & $1.36 \mathrm{c}$ & $0.24 b$ & $15.19 \mathrm{c}$ & $857.69 c$ & $12.89 \mathrm{~d}$ & $51.77 \mathrm{c}$ \\
\hline $\mathrm{T}_{4}$ & $34.67 \mathrm{~b}$ & $8989.70 b$ & $1.53 \mathrm{~b}$ & $0.25 b$ & $18.10 \mathrm{~b}$ & $1006.80 \mathrm{~b}$ & $10.22 \mathrm{e}$ & $76.71 b$ \\
\hline $\mathrm{T}_{5}$ & $36.97 \mathrm{a}$ & $9330.00 \mathrm{a}$ & $1.62 \mathrm{a}$ & $0.28 \mathrm{a}$ & $18.49 \mathrm{a}$ & $1011.40 \mathrm{a}$ & $10.03 \mathrm{f}$ & $79.13 \mathrm{a}$ \\
\hline
\end{tabular}

Means with the same letter are not significantly different at $5 \%$ level by DMRT. Here, $\mathrm{T}_{0}=\mathrm{N}_{0} \mathrm{P}_{150} \mathrm{~K}_{100} \mathrm{~kg} / \mathrm{ha} / \mathrm{yr}, \mathrm{T}_{1}=\mathrm{N}_{80} \mathrm{P}_{150} \mathrm{~K}_{100} \mathrm{~kg} / \mathrm{ha} / \mathrm{yr}$, $\mathrm{T}_{2}=\mathrm{N}_{160} \mathrm{P}_{150} \mathrm{~K}_{100}$ $\mathrm{kg} / \mathrm{ha} / \mathrm{yr}, \mathrm{T}_{3}=\mathrm{N}_{240} \mathrm{P}_{150} \mathrm{~K}_{100} \mathrm{~kg} / \mathrm{ha} / \mathrm{yr}, \mathrm{T}_{4}=\mathrm{N}_{320} \mathrm{P}_{150} \mathrm{~K}_{100} \mathrm{~kg} / \mathrm{ha} / \mathrm{yr}$ and $\mathrm{T}_{5}=\mathrm{N}_{400} \mathrm{P}_{150} \mathrm{~K}_{100} \mathrm{~kg} / \mathrm{ha} / \mathrm{yr}$. 


\section{DISCUSSION}

\section{A. Effect of Nitrogen on Mulberry Leaf Yield and Quality}

The increased doses of $\mathrm{N}$ significantly improved the leaf yield and quality of mulberry plant. In our study we applied six levels of $\mathrm{N}$ at the rate of $0 \mathrm{~kg} \mathrm{~N}, 80 \mathrm{~kg} \mathrm{~N}, 160 \mathrm{~kg} \mathrm{~N}$, $240 \mathrm{~kg} \mathrm{~N}, 320 \mathrm{~kg} \mathrm{~N}$ and $400 \mathrm{~kg} \mathrm{~N} / \mathrm{ha} / \mathrm{yr}$ respectively with BSRTI recommended $\mathrm{P}$ and $\mathrm{K} @ 150 \mathrm{~kg} \mathrm{P}$ and $100 \mathrm{~kg} \mathrm{~K} / \mathrm{ha} / \mathrm{yr}$ in four splits doses. The experimental result showed that the yield contributing characters of mulberry plant viz: nodes per meter, total branches number per plant, total branch height per plant, length of longest shoot per plant, total shoot weight per plant, 10-leaf area per plant, 10-leaf weight per plant and total leaf yield/ha/year were highly significant $(P \leq 0.001)$ for the treatment of $\mathrm{T}_{5}\left(\left(\mathrm{~N}_{400} \mathrm{P}_{150} \mathrm{~K}_{100}\right.\right.$ $\mathrm{kg} / \mathrm{ha} / \mathrm{yr}$ ) as compared to the other treatments (see Table I). The highest mulberry leaf yield was $51.88 \mathrm{mt} /$ ha/year for the treatment of $\mathrm{T}_{5}$ which is $46.14 \%$ higher than the maximum yield of control treatment. However, the interaction effect of plant age $\times$ fertilizer treatments was not statistically significant $(P \leq 0.05)$ except leaf yield/ha/year (see Table II). Similarly, the maximum average biochemical properties percentage viz: moisture (78.59), chlorophyll-a (5.41), chlorophyll-b (59.23), total sugar (6.51), soluble carbohydrate (10.44), reducing sugar (4.08) and crude protein (23.22) were recorded for $T_{5}$ treated mulberry plant which was statistically higher than the other treatments. These findings are similar with the previous findings of [35]. They were applied $0 \mathrm{~kg}, 200 \mathrm{~kg}, 300 \mathrm{~kg}$ and $400 \mathrm{~kg} \mathrm{~N} / \mathrm{ha} / \mathrm{yr}$ with different doses of $\mathrm{P}$ and $\mathrm{K}$ along with one and two irrigations respectively.

Among the different doses of $\mathrm{N}$ treatments, the rate of $400 \mathrm{~kg} \mathrm{~N} / \mathrm{ha} / \mathrm{yr}$ with two irrigations showed the significantly highest values both for the yield components (plant height, number of branches per plant, number of leaves per branches and leaf yield per plant) and leaf quality parameters (leaf moisture, crude protein, reducing sugar, total sugar, starch, and soluble carbohydrate except mineral) which is more or less similar with our findings. Such results also reported by [36] who found that the application of $400 \mathrm{~kg} \mathrm{~N}$ with $200 \mathrm{~kg}$ $\mathrm{P}$ and $150 \mathrm{~kg} \mathrm{~K}$ the mulberry leaf yield was increased $77.92 \%$ over the control treatment and the leaf constituents viz: moisture (\%), chlorophyll-a, chlorophyll-b, total sugar (\%), soluble carbohydrate $(\%)$, reducing sugar and crude protein (\%) except total mineral contents increased gradually due to progressive increase of NPK fertilizers. He [37] also applied the $\mathrm{N} @$ of $0,150,300,600$ and $900 \mathrm{~kg} / \mathrm{ha} / \mathrm{yr}$ and found that the leaf yield was increased by $88 \%$ in the highest dose compared to the control $\left(\mathrm{T}_{0}\right)$ treatment, leaf yield per plant of $\mathrm{T}_{1}, \mathrm{~T}_{2}$ and $\mathrm{T}_{3}$ were increased by $25.96,41.60$ and $49.29 \%$ respectively. Similarly, [38] found that the application of 360 $\mathrm{kg} \mathrm{N}: 180 \mathrm{~kg}$ P: $180 \mathrm{~K}$ gave the maximum number of leafs, average weight of leaves and height of mulberry plant. However, they did not explain their speculation about their experimental findings. But our speculation is the applied $\mathrm{N}$ with $\mathrm{P}$ and $\mathrm{K} @\left(\mathrm{~N}_{400} \mathrm{P}_{150} \mathrm{~K}_{100} \mathrm{~kg} / \mathrm{ha} / \mathrm{yr}\right)$ was comparatively optimum and available than the other treatments. As a results, the $\mathrm{N}$ as well as the other related nutrients specially $\mathrm{P}, \mathrm{K}$ uptake form the soil, assimilation and utilization through the proliferated mulberry roots was comparatively maximum which directly improved the several key functions, including energy transfer, photosynthesis rate, transformation of sugars, nutrient movement within the plant cell, also many structural, genetics, metabolic components, various physiological process, chlorophyll, and protein contents. Consequences, the growth, development, leaf area production, leaf area duration as well as net assimilation rate of mulberry plant was increased in terms the growth parameters, leaf yield as well as the leaf quality viz; moisture, chlorophyll-a, chlorophyll-b, total sugar, soluble carbohydrate, reducing sugar and crude protein except total mineral, were greater for the treatment of $\mathrm{T}_{5}$, which is lined with the previous findings of [39] who reported that maximum leaf area and total leaf biomass of plants are a determinant of higher crop yield. Because nitrogen is the essential constituent of protein, nucleic acids, chlorophyll and growth hormones [40]. Besides, Proper growth and development of plants require optimum supply of nitrogen. Because too little application of $\mathrm{N}$ directly reduces crop yield while excess supply of $\mathrm{N}$ also causes negative effects on plant and this issue getting focus continuously on crop production [41].

\section{B. Impact of Ages of Mulberry Plant on Leaf Yield and Quality}

The ages of mulberry plant significantly increased the leaf yield and quality of mulberry plant. Results of this study showed that the (6-10) years ages of older mulberry plant gave the maximum leaf yield with higher leaf quality than the (0-5) year's ages of plant. In our study we applied $0 \mathrm{~kg}$ $\mathrm{N} / \mathrm{ha} / \mathrm{yr}, 80 \mathrm{~kg} \mathrm{~N} / \mathrm{ha} / \mathrm{yr}, 160 \mathrm{~kg} / \mathrm{ha} / \mathrm{yr} \mathrm{N}, 240 \mathrm{~kg} \mathrm{~N} / \mathrm{ha} / \mathrm{yr}$, $320 \mathrm{~kg} \mathrm{~N} / \mathrm{ha} / \mathrm{yr}$ and $400 \mathrm{~kg} \mathrm{~N} / \mathrm{ha} / \mathrm{yr}$ respectively with $150 \mathrm{~kg}$ $\mathrm{P} / \mathrm{ha} / \mathrm{yr}$ and $100 \mathrm{~kg} \mathrm{~K} / \mathrm{ha} / \mathrm{yr}$ on (0-5) years and (6-10) years old mulberry plant. Among the (0-5) and (6-10) years ages of mulberry plant the growth and yield contributing parameters viz: nodes per meter, total branches number per plant, total branch height per plant, 10-leaf area per plant, 10-leaf weight per plant and total leaf yield/ha/year except length of longest shoot and total shoot weight per plant were significantly increased for (6-10) years ages of older plant than the (0-5) years ages of younger plant. However, the maximum average mulberry leaf yield was $51.88 \mathrm{mt} / \mathrm{ha} /$ year for (6-10) years ages of mulberry plant which was $6.57 \%$ higher than the maximum average yield $48.68 \mathrm{mt}$. of (0-5) year's plant. Also, the leaves quality viz: moisture (\%), chlorophyll-a, chlorophyll-b, total sugar (\%), soluble carbohydrate (\%), reducing sugar and crude protein $(\%)$ were $1.81 \%, 167.82 \%$, $2.6 \%, 5.34 \%, 5.24 \%, 2.25 \%$ and $1.8 \%$ respectively higher in (6-10) years ages of older plant than the average maximum leaf quality of (0-5) years ages of plant.

Such type of study is totally new in mulberry crop. Our speculation is the $\mathrm{N}$ absorption rate by the older (6-10) years ages of older mulberry plant was comparatively higher than the (0-5) years ages of younger mulberry plant due to the well-developed, larger, deeper root system and larger leaves of older plant was contributed the rapid and maximum photosynthesis as well as enhances physiological activity and $\mathrm{N}$ use efficiency of the plant. As a result, the growth and development of the (6-10) years ages of older mulberry plant were better interns the leaf yield and essential leaf constituents viz: protein, chlorophyll, moisture, mineral, total sugar, soluble carbohydrate and reducing sugar were 
comparatively high in the older mulberry plant. Because in previous study [42] found that the $\mathrm{N}$ absorption is increased with plant age of marigold seedlings. They were treated the seedlings of 30, 35, 40, 45 and 50 days old marigold (Tagete serecta Big. Inca Gold) in $500 \mathrm{ml}$ plastic pots containing a 1 peat: 1 per liter $(\mathrm{v} / \mathrm{v})$ with several fertilizer levels $(\mathrm{N}$ at 20 , 50,80 and $100 \mathrm{mg} /$ Liter); solution nutrient levels in the medium and found $\mathrm{N}$ absorption was increased by the older plants than the younger plants even the older plants $(>40$ days) absorbed at least $88 \%$ of the $\mathrm{N}$ solution regardless of $\mathrm{N}$ treatment. Similarly, [43] reported that when the plants root completely developed and leaves also become wider in size then the $\mathrm{N}$ utilization increases, besides the deeper root system enhances the intake of $\mathrm{N}$, while larger leaves contribute rapid and maximum photosynthesis process which stimulates physiological activity of plant that help in $\mathrm{N}$ use efficiency.

\section{Common Diseases of Mulberry Plant Suppresses due to Elevated N Application in Soil}

Soil applied nitrogen with BSRTI recommended basal dose of phosphorus and potassium showed various degrees of disease severity of common diseases viz: powdery mildew, leaf spot and tukra in (6-10 years) ages of mulberry plant. In case of powdery mildew and leaf spot the average lowest incidence, percentages were 1.08 and 0.55 respectively for $\mathrm{T}_{4}$ $\left(\mathrm{N}_{320} \mathrm{P}_{150} \mathrm{~K}_{100} \mathrm{~kg} / \mathrm{ha} / \mathrm{yr}\right)$ treatment and maximum average percentage were 1.54 and 4.42 respectively for control treatment. But in case of tukra disease the average lower incidence percentage was 1.36 for the treatment of $\mathrm{T}_{5}\left(\mathrm{~N}_{400}\right.$ $\mathrm{P}_{150} \mathrm{~K}_{100} \mathrm{~kg} / \mathrm{ha} / \mathrm{yr}$ ) and the maximum average incidence percentage was 4.42 for control treatment (see Table IV). These findings showed that optimum level of $\mathrm{N}$ application suppress the common disease of mulberry plant. This could be due to the reason that high $\mathrm{N}$ rate the metabolic and enzymatic functions of the mulberry plant was changed which developed defense system against the pathogen in terms, the incidence of diseases were comparatively low in the treatments of $\mathrm{T}_{4}$ and $\mathrm{T}_{5}$.

\section{Effect of Elevated Nitrogen on Silkworm Rearing Performance}

The feeding of mulberry leaves treated by high rate of soil applied nitrogen with BSRTI recommended basal dose of potassium and phosphorus significantly improved the silkworm rearing performances as well as increased the cocoon productivity and minimized the rendita of raw silk. Results of this study showed that the average silkworm rearing performances viz: wt. of 10 matured larval (g), effective rate of rearing by number, single cocoon wt. (g), single shell wt. (g), SR\%, highest filament length (m) and silk cocoon yield/100dfls $(\mathrm{kg})$ were comparatively maximum for the feeding of mulberry leaves of 6-10 years ages of mulberry plant treated by the treatment of $\mathrm{T}_{5}\left(\mathrm{~N}_{400} \mathrm{P}_{150} \mathrm{~K}_{100} \mathrm{~kg} / \mathrm{ha} / \mathrm{yr}\right)$ than the other treatments (see Table V). This finding more or less similar with the previous finding of [44] who found that larvae feed on balanced NPK fertilized mulberry plantations leaves increased the fresh cocoon weight, cocoon shell weight; cocoon shell ratio, cocooning percentage, silk productivity, hatchability, filament length, and filament weight and size may be due to existence of higher amounts of essential nutrients from NPK fertilization than untreated. It may be due to the feeding of higher essential nutrients enriched mulberry leaves by the silkworm which was treated by the treatment of $\mathrm{T}_{5}\left(\mathrm{~N}_{400} \mathrm{P}_{150} \mathrm{~K}_{100} \mathrm{~kg} / \mathrm{ha} / \mathrm{yr}\right)$ because quality of mulberry leaves affects growth rate, developmental period, body weight, and survival rate of larvae, as well as influencing the subsequent fecundity, longevity, movement and competitive ability of the adults [45]. So, the nutritional status of mulberry leaves can be improved by enriching them with extra nutrients in order to increase larval growth and improve cocoon characteristics [46].

\section{CONCLUSION}

This study concluded that the combined application of nitrogen with BSRTI recommended basal dose of phosphorus and potassium is a proactive fertilizer management strategy for mulberry plant production. This strategy improves mulberry plant growth, leaf yield, quality, suppress of foliar diseases as well as improve silk cocoon parameters. Out of the six levels of nitrogen treatments, treatment $\mathrm{N}_{400} \mathrm{P}_{150} \mathrm{~K}_{100}$ $\mathrm{kg} / \mathrm{ha} / \mathrm{yr}$ followed by treatment $\mathrm{N}_{320} \mathrm{P}_{150} \mathrm{~K}_{100} \mathrm{~kg} / \mathrm{ha} / \mathrm{yr}$ showed overall better performances.

\section{ACKNOWLEDGMENT}

The authors are grateful tothe technical staff of Bangladesh Sericulture Research and Training Institute (BSRTI), Rajshahi, Bangladesh for their help regarding the experiment. The authors are also like to thank the Soil Resources Development Institute (SRDI), Rajshahi, Bangladesh for its help regarding soil physical and chemical properties analysis. Lastly, authors are appreciative to the Director of Bangladesh Sericulture Research and Training Institute (BSRTI), Rajshahi, for allowing us approval to use the mulberry garden, valuable support and providing laboratory facilities for analytical analysis for this research study.

\section{FUNDING}

This research study was conducted through the financial funding of World Bank, IFAD, and GoB through the Ministry of Agriculture. So, the authors would like to recognize to the World Bank for providing the research fund and organizing the PBRG by Bangladesh Agricultural Research Council (BARC), Farmgate, Dhaka. It was valuable to remark the cooperation and rapid responses of PIU-BARC, NATP-2 in respect of field implementation of the project in several locations.

\section{CONFLICT OF INTEREST}

Authors declared that they do not have any conflict of interest.

\section{REFERENCES}

[1] Jian, Q, Ningjia H, Yong W, Zhonghuai X. Ecological issues of mulberry and sustainable development. Journal of Resources \& Ecology.2012; 3(4): 330-339. 
[2] Singheal BK, Malav R, Sarkar A, Datta RK. Nutritional disorders of mulberry (morusspp.): iii- leaf nutrient guide for secondary nutrients, Sericologia. 1999; 39(40): 599-609.

[3] Venkataramu BV. Nutrient status of different mulberry varieties and its effect on growth and development of Bombyxmori L. M.Sc. (Sericulture.) Thesis, UAS, Bangalore. 1986; 89.

[4] Guttierrez WA, Shew HD, Melton TA. Source of inoculums and management of rhizoctoniasolani causing damping off on tobacco transplants under greenhouse conditions. Plant Disease. 1997; 81: 604 608.

[5] Nasreen A, Cheema GM, Ashfaq M. Rearing of milk BombyxmoriL. on alternative food parts. Pakistan Journal of Biological Sciences. 1999; 2: 843-845.

[6] Gallegos-Cedillo VM, Urrestarazu M, Álvaro, JE. Influence of salinity on transport of nitrates and potassium by means of the xylem sap content between roots and shoots in young tomato plants. Journal of Soil Science and Plant Nutrition. 2016; 16(4): 991-998.

[7] Shankar MA, Rangaswamy BT. Effect of applied nitrogen and potassium on mulberry leaf yield and uality in relation to silkworm cocoon characters. Better Crops International, India. 1999; 13(2): 2021.

[8] Shankar MA, Nagaraju PA, Rangasw BT. Response of mulberry to application of micronutrients and their impact on cocoon production and grainage parameters. The Proceeding of the XVIIth International Sericulture Commission Congress, Cairo- Egypt. 1999; 12-16.

[9] Tzenov P, Petkov Z. Nitrogen balanced study at silkworm butterfly (BombyxmoriL.) during the early and late spring season. Zhivotnov" dni Nauki. 1994;31(7-9): 156-159.

[10] Sengupta AK, Kumar P, Baig M, Govindaiah Hand book of pest and disease control of mulberry and silkworm. Economic and Social Commission for Asia and the Pacific, Thailand. 1990;88.

[11] Yashihiko A. Sericulture in tropics. Association for international cooperation of agriculture and forestry, Tokyo, Japan, 1995.

[12] Khan MA, Dhar A, Zeya SB, Trag, AR. Pests and Diseases of Mulberry and Their Management. Bishen Singh Mahendra Pal Singh 23-A, New Connaught Place, Dehradun-248 001(INDIA).2004.

[13] Rabbel MA. Studies on important fungal diseases of mulberry (Morus sp.) leaf in Bangladesh and their control. Phd Thesis, University of Rajshahi, Bangladesh.1995.

[14] Veresoglou SD, Barto EK, Menexes G, Rillig MC. Fertilization affects severity of disease caused by fungal plant pathogens. Plant Pathology. 2013; 62: 961-969.

[15] Mitchell CE, Reich PB. Tilman, D, Groth, JV. Effects of elevated CO2, nitrogen deposition and decreased species diversity on foliar fungal plant disease. Global Change Biology.2003; 9: 438-51.

[16] Haber F, Klemensiewicz Z. The results of their research on the glass electrode in the society of chemistry in karlsruhe. The Journal of Physical Chemistry.1909.

[17] Heanes DL. Determination of organic C in soils by an improved chromic acid digestion and spectrophotometric procedure, comm. Soil Science and Plant Analysis. 1984;15: 1191-1213.

[18] Piper CS. Soil and plant analysis. Adelaide University. Hassel Press, Australia. 1950; 368

[19] Subbiah VB, Asija GL. A rapid procedure for estimation of available nitrogen in soils. Current Science. 1956; 25: 259-260.

[20] Podder M, Akter M, Saifullah MSA, Roy S. Impacts of plough pan on physical and chemical properties of soil. Journal of Environmental Science \& Natural Resources. 2012; 5(1): 289-294.

[21] Petersen L. Soil analytical methods soil testing management and development. Soil Resources Development Institute, Dhaka Bangladesh. 1996; 1-28.

[22] Biswas A, Alamgir M, Haque SMS, Osman KT. Study on soils under shifting cultivation and other land use categories in chittagong hill tracts. Bangladesh Journal of Forestry Research.2012; 23(2): 261265.

[23] Huq MS, Alam MD. A handbook on analyses of soil, plant and water. Bacer-Du, University of Dhaka, Bangladesh. 2005; 13-40.

[24] Soltanpour PN, Workman S. Modification of the nh4hco3-dtpa soil test to omit carbon black. Communications in Soil Science and Plant Analysis. 1979; 10: 1411-1420.

[25] Vijayan K, Tikader A, Das KK, Roy BN, Pavan KT. Genotypic influence on leaf moisture content and moisture retention capacity in mulberry (Morus spp.). Bulletin Sericulture Research.1996;7: 95-98.

[26] Hiscox JD, Israelstam GF. Different methods of chlorophyll extraction. Canadian Journal of Botany. 1979; 57: 1332-1332.

[27] Arnon DI. Copper enzymes in isolated chloroplasts. Polyphenoloxidase in Beta vulgaris. Plant Physiol. 1949; 24: 1-15

[28] AOAC. Association of Official Analytical Chemists. Method of analysis. 13thedition. Washington, Dc, USA.1980; 13044.
[29] Wong SY. The use of persulfate in the estimation of nitrogen by the arnold-gunning modification of kjeldahl's method. Journal of Biological Chemistry. 1923; 55:427.

[30] Miller LG. Use of dinitrosalicylic acid reagent for determination of reducing sugar. Analytical Chemistry. 1972; 426-428.

[31] Loomis EW, Shull AC. Methods in plant physiology. Mcgraw-Hill Book Company, New York.1937.

[32] DubiosM, Giles KA, Hamilton TK, Robeos RA, Smith R. Calorimetric determination of sugars and related substances. Analytical Chemistry. 1956; 28: 250-256.

[33] Piper CS. Soil and Plant Analysis, Hans Publishers, Bombay.1996.

[34] Rai VR, Mamtha T. Seedling diseases of some important forest tree species and their management. Working Papers of the Finish Forest Research Instiatute. 2005; 11.

[35] Paul NK, Qaiyyum MA. Effect of different levels of npk fertilizer sand irrigation on yield and nutritive quality of mulberry leaf. Bangladesh Journal of Agricultural Research. 2009; 34(3): 435-442.

[36] Miah MAB. Studies on the growth and yield of mulberry (Morusalba L.). $\mathrm{PhD}$ thesis. University of Rajshahi, Bangladesh.1989.

[37] Ray D. Effect of different doses of ammonium sulphate and lime on soil composition, leaf yield and nutritive value of mulberry leaf. Annual Report, Central Sericulture Research and Training Institute, Berhamapur, India. 1978; 51-55.

[38] Shinde KS, Avhad SB, Jamdar SV, Hiware CJ. Impact of spacing, fertilizer on the productivity of mulberry (Morusalba L.) V1 Variety. Life Science Bulletin.2012; 9(2): 276-280.

[39] RafiqMA, Ali A, Malik MA, Hussain M. Effect of fertilizer levels and plant densities on yield and protein contents of autumn planted maize. Pakistan Journal of Agricultural Sciences. 2010;47: 201-208.

[40] Barker AV, Maynard DN, Mills HA. Variations in nitrate accumulation among spinach cultivars. Journal of American Society for Horticultural Science. 1974; 99: 32-134.

[41] Magistad OC, Reitemeier RF, Wilcox LV. Determination of soluble salts in soils. Soil Science. 1945;59: 65-75

[42] Deborah A, Tolman1, Alexander X, Niemiera, Robert D, Wright Influence of plant age on nutrient absorption for marigold seedlings. Horticultural Science. 1990; 25(12): 1612-1613

[43] Leghari SJ, Buriro M, Jogi QD, Kandhro MN, Leghari AJ. Depletion of phosphorus reserves, a big threat to agriculture: challenges and opportunities. Science International, (Lahore). 2016; 28(3): 2697 2702.

[44] Kamel HM. The effect of fertilized mulberry leaves with balanced npk on the biological, quantitative and technological parameters of silkworm, Bombyxmori L. Middle East Journal of Agriculture Research. 2014; 3(4): 988-993.

[45] Parra JRP. Consumoeutilizaçào De Alimentosporinsetos. In: Panizzi, A. R.\& Parra, J. R. P. (eds) Ecologianutricional De Insetosesuas Implicaçòes no Manejo de Pragas. Manole, Sào Paulo. 1991; 359.

[46] Sengupta K, Singh BD, Mustafa JC. Role of vitamins in silkworm nutrition. Indian Journal of Sericulture. 1992; 11(1): 11-19.

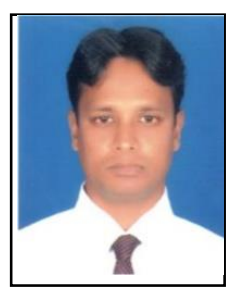

\section{Faruque Ahmed}

Birth place: Rajshahi, Date of birth: 31.12.1983, Educational background: Master of Science in Agronomy and $\mathrm{PhD}$ Fellow (Current), Field: Agronomy, Institution: Rajshahi University, City: Rajshahi, State or Country: Bangladesh, Year of Degree: 2009, Major field of study: Agronomy.

His work experience: 10 years, Job title: Senior Scientific Officer, Current job location: Bangladesh Sericulture Research and Training Institute (BSRTI), Rajshahi, Bangladesh. He has been published 13 research publication in different peer review international journal. His current and previous research interest is mulberry agronomy.

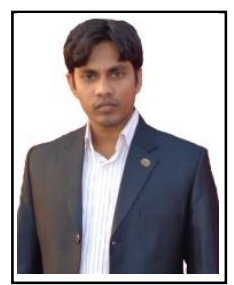

\section{Md. ShakhawatHossain}

Birth place: Rajshahi, Date of birth: 15.11.1984 Educational background: Master of Science (Chemistry) and PhD Fellow (Current), Silk sericin protein, Institution: Rajshahi University, City: Rajshahi, State or Country: Bangladesh, Year of Degree: 2007. Major field of study: Organic Chemistry.

His work experience: 10 years, Job title: Senior Scientific Officer, Current job location: Bangladesh Sericulture Research and Training Institute (BSRTI), Rajshahi, Bangladesh He has been published 8 research publication in different international journal. His current and previous research interest in silk protein, soil \& mulberry leaf nutrition. 


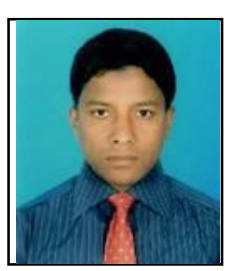

Md. Aftab Uddin

Birth place: Rajshahi, Date of birth: 30.12.1985,

Educational background: Master of Zoology,

Institution: Rajshahi University, City: Rajshahi, State

or Country: Bangladesh, Year of Degree: 2008, Major

field of study: Entomology

His work experience: 10 years, Job title: Senior

Scientific Officer, Current job location: Bangladesh

Sericulture Research and Training Institute (BSRTI),

Rajshahi, Bangladesh. He has been published 05 research publication in different peer review international journal. His current and previous research interest is Entomology.

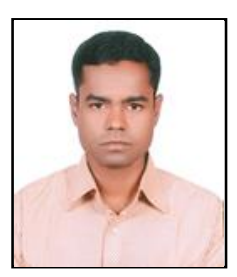

\section{Oli Ahmed}

Birth place: Rajshahi, Date of birth: 01.01.1985, Educational background: Master of Political Science, National University, Bangladesh and $\mathrm{PhD}$ Fellow,Jahangirnagar University.

His work experience: 10 years, Job title: Personal Assistant to Director, Current job location: Bangladesh Sericulture Research and Training Institute (BSRTI), Rajshahi, Bangladesh. He has been published 05 research publication in different peer review international journal. His current and previous research interest is Mulberry Extension. 